\title{
Masticatory efficiency, quality of life, comfort, retention and satisfaction on digital denture: case report
}

\author{
Eficiência masticatória, qualidade de vida, conforto, retenção \\ e satisfação com prótese total digital: caso clínico
}

\author{
Adriana da Fonte Porto CARREIRO ${ }^{1}$ iD https://orcid.org/0000-0002-0833-1926 \\ Rachel Gomes CARDOSO1 ID https://orcid.org/0000-0001-9343-6185 \\ Ana Clara Soares Paiva TÔRRES ${ }^{1}$ iD https://orcid.org/0000-0002-7525-3171 \\ Andréa Fabiana LIRA1 ${ }^{\text {ID }}$ https://orcid.org/0000-0002-8529-0144 \\ Laércio Almeida de MELO1 ${ }^{\text {ID }}$ https://orcid.org/0000-0002-9276-0116 \\ Valerie COOPER ${ }^{2}$ iD https://orcid.org/0000-0001-8992-4688
}

\section{ABSTRACT}

The aim of this study was to describe a clinical protocol for fabrication of maxillary and mandibular dentures using CAD/CAM technology. Further, digital and conventional dentures fabricated for the same patient were compared. The comparison was based on patient's satisfaction, comfort, retention, number of follow-up sessions, masticatory performance and quality of life. No laboratorial step was needed for CAD/CAM fabrication and less sessions were required up to denture insertion. Compared to the conventional dentures, digital dentures provided better satisfaction, comfort and retention and required less follow-up sessions. Both dentures presented similar results about masticatory performance and quality of life. As a conclusion, digital denture is a viable treatment alternative for edentulous patients. However, controlled and randomized clinical trials are required to reveal the real benefits of this treatment alternative compared to the conventional denture.

Indexing terms: Computer-aided design. Denture, complete. Dentistry.

\section{RESUMO}

O objetivo deste estudo foi descrever um protocolo clínico para a fabricação de próteses superiores e inferiores usando a tecnologia CAD/CAM. Além disso, as próteses digitais e convencionais fabricadas para o mesmo paciente foram comparadas. A comparação foi baseada na satisfação, conforto, retenção, número de sessões de acompanhamento, desempenho mastigatório e qualidade de vida do paciente. Nenhuma etapa laboratorial foi necessária para a fabricação de CAD/CAM e menos sessões foram necessárias até a inserção da prótese. Comparadas às próteses convencionais, as próteses digitais proporcionavam melhor satisfação, conforto e retenção e exigiam

$\boldsymbol{\nabla} \boldsymbol{\nabla} \boldsymbol{\nabla}$

1 Universidade Federal do Rio Grande do Norte, Departamento de Odontologia. Av. Salgado Filho, 1787, Lagoa Nova, 59056-000, Natal, RN, Brasil. Correpondence to LA MELO. Email: <laercio_melo91@hotmail.com>.

2 Ohio State University, Department of Dentistry. Columbus, Ohio, United States.

$\boldsymbol{v} \boldsymbol{\nabla} \boldsymbol{v}$

How to cite this article

Carreriro AFP, Cardodo RG, Tôrres Acsp, Lira AF, Melo LA, Cooper V. Digital complete denture: case report. RGO, Rev Gaúch Odontol. 2021;69:e20210052. http://dx.doi.org/10.1590/1981-863720210005220200036 
menos sessões de acompanhamento. Ambas as próteses apresentaram resultados semelhantes sobre desempenho mastigatório e qualidade de vida. Como conclusão, a prótese digital é uma alternativa viável para o tratamento de pacientes desdentados. No entanto, ensaios clínicos controlados e randomizados são necessários para revelar os benefícios reais dessa alternativa de tratamento em comparação com a prótese convencional.

Termos de indexação: Odontologia. Prótese total. Desenho assistido por computador.

\section{INTRODUCTION}

In the past years, the Computer Aided Design/ Computer Aided Machining (CAD/CAM) technology has been widely used and extended to the fabrication of complete dentures $[1,2]$. Data for designing of a digital prosthesis can be acquired from a impression or intraorally [3].

The most recent literature has tried to eliminate anatomic and functional impressions for fabrication of complete dentures using CAD/CAM technology [4]. Despite of the techniques for intraoral scanning in complete edentulous patients, the presence of smooth and undefined structures results in poor digitalization with several errors [5]. This limitation is even more critical for mandibular ridge exhibiting undifferentiated structures for intraoral scanning [4].

Although impression is still required for fabrication of digital dentures, there are several advantages compared to the conventional denture [6-8]. Digital technology requires less clinical sessions up to denture insertion, less or no laboratorial steps and exhibits no polymerization shrinkage. In addition, record of digital data provides easier replacement of complete dentures [6-8].

Although such advantages had been described in previous studies, comparison between conventional and digital techniques for rehabilitation of complete edentulous patients is still based on laboratorial studies [9-12]. Furthermore, authors comparing conventional and digital dentures in the same patient did not compare masticatory performance between both treatment alternatives [13]. So, the aim of this study was to describe a clinical protocol for rehabilitation with maxillary and mandibular dentures fabricated with CAD/CAM technology. In addition, digital and conventional dentures fabricated for the same patient were compared. Patient's satisfaction, comfort, retention, number of follow-up sessions, masticatory performance and quality of life were evaluated. The null hypothesis assumed that there is no difference between both protocols for fabrication of complete dentures.

\section{CASE REPORT}

Female patient, 69years old, maxillary and mandibular denture wearer, required specialized dental treatment for replacement of old dentures. After clinical exam, tooth wear, alteration in occlusal plane and poor retention were observed in both maxillary and mandibular dentures. The treatment planning was replacement of both dentures using conventional and digital processing techniques. The old dentures were not used as a reference since esthetic and functional characteristics were unappropriated.

For conventional technique, maxillary anatomic impression was taken with irreversible hydrocolloid (Jeltrate, Dentsply ${ }^{\odot}$ ) while mandibular impression was taken with condensation silicone putty material (Perfil-putty and catalyst Perfil Club, Coltene()). After adjustment of individual tray, border molding was done with impression compound (Exata- $\mathrm{DFL}^{\circledR}$ ) and functional impression was taken with polyether (Impregum, 3M○). Then, adjustment of wax rim, maxilomandibular record and mounting in semi-adjustable articulator were done. Lip support, occlusal plane, occlusion and esthetics of artificial teeth mounted in wax rim were evaluated at clinical trial. Then, maxillary and mandibular dentures were inserted and the patient was instructed about oral care. A conventional protocol for denture processing was followed; including flasking, wax removal, condensation, pressing, polymerization, deflasking, remounting in articulator, occlusal adjustment and finishing/polishing.

After 3 months of dentures insertion, a validated questionnaire about oral health-related quality of life in edentulous people (OHIP-EDENT) was applied [14]. Further, the number of follow-up sessions was recorded and masticatory performance was evaluated by the sieving method validated by Slagter et al. [15]. After that, digital dentures were fabricated. First, maxillary anatomic impression was taken with irreversible hydrocolloid (Jeltrate, Dentsply ${ }^{\odot}$ ) while mandibular impression was taken with condensation silicone (Perfil-putty and catalyst Perfil Club, Coltene $^{\odot}$ ) (figures $1 \mathrm{~A}$ and $1 \mathrm{~B}$ ). In the same session, adjusted wax rims were used as individual trays for functional 
impression. Border and functional impression were taken with polyvinyl siloxane (Express $X T-3 M$ ) putty-wash technique (figures $1 \mathrm{C}$ and 1D). Then, maxillomandibular record was

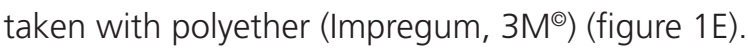

After that, the impression and maxillomandibular record were scanned in the laboratory (3Shape Dental
System) (figure 2A, 2B, and 2C). Dentures were virtually planned with digital data (figure 2D) and testing dentures were fabricated (Figures $3 \mathrm{~A}$ and $3 \mathrm{~B}$ ) for clinical trial. After approval and selection of artificial teeth, a block of polymethyl methacrylate resin (AvaDent Digital Dental) was machined in one step (denture base and teeth) for

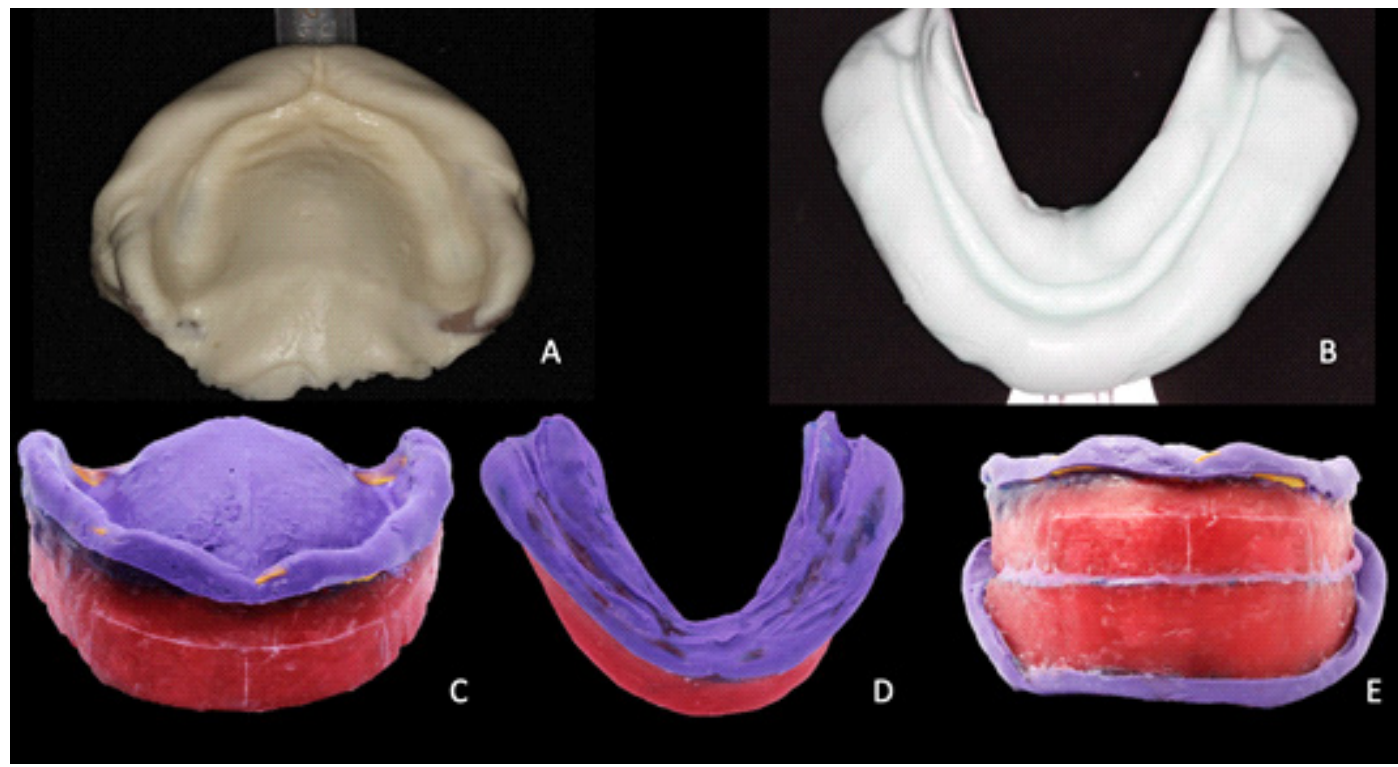

Figure 1. A) Anatomic impression of maxillary ridge. B) Anatomic impression of mandibular ridge. C) Maxillary functional impression using adjusted wax rim. D) Mandibular functional impression using adjusted wax rim. E) Maxillomandibular record.

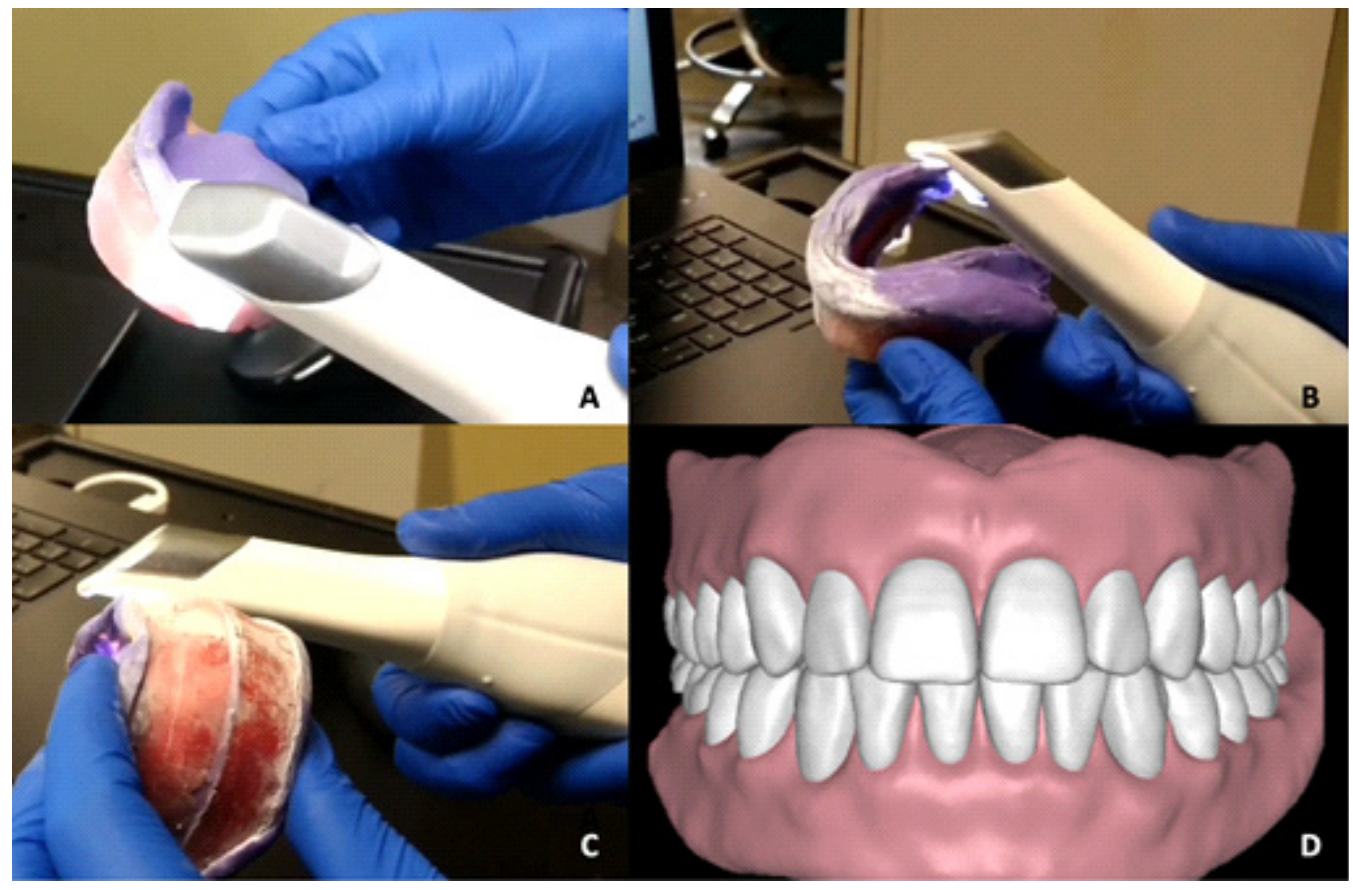

Figure 2. A) Scanning of maxillary impression. B) Scanning of mandibular impression. C) Scanning of maxillomandibular record. D) Digital planning of maxillary and mandibular dentures. 
fabrication of maxillary and mandibular dentures (figures $3 C$ and 3D). At third session, dentures were inserted and the patient was instructed about oral care (figure 3E).

Similar to conventional dentures, quality of life and masticatory performance were evaluated 3 months after digital dentures insertion. Before insertion of digital dentures, the patient was instructed to wear the old dentures during 15 days in order to avoid the influence of new conventional dentures on the evaluation of digital dentures. The number of follow-up sessions was also recorded and the patient was asked about comfort, retention and satisfaction with each denture. To assess these variables, a questionnaire proposed by Sato et al. [16] and validated by Cunha (2004), where satisfaction was assessed in relation to the following criteria: chewing, tasting, phonetics, painful symptoms, aesthetics, adaptation, retention and comfort [17].

\section{DISCUSSION}

The null hypothesis was partially accepted. Data about OHIP-EDENT and masticatory performance were similar for both digital and conventional dentures. However, digital dentures showed better results about comfort, retention and satisfaction. In addition, less follow-up sessions were needed for digital dentures fabricated with CAD/CAM technology.
OHIP-EDENT score for both dentures was 4 (table 1), indicating low impact of oral health on quality of life. These values are in accordance with clinical studies about oral health-related quality of life in denture wearers [18]. Since this evaluation was conducted after adjustment of denture base and a certain period of adaptation to denture wear, pain was not reported in both situations [19-21]. Furthermore, since both dentures were removable and supported by mucosa, the evaluation of OHIPEDENT domains (functional limitation, pain, psychological discomfort, physical disability, psychological disability, social disability and handicap) were similar. The same behavior was found for masticatory performance.

Table 1. OHIP-EDENT scores for digital and conventional dentures.

\begin{tabular}{lccc}
\hline \multirow{2}{*}{ Variables } & Digital denture & & Conventional denture \\
\cline { 2 - 2 } & Mean & & Mean \\
\hline Functional limitation & 2.0 & & 2.0 \\
Pain & 0.0 & 0.0 \\
Psychological discomfort & 0.0 & 0.0 \\
Physical disability & 2.0 & 2.0 \\
Psychological disability & 0.0 & 0.0 \\
Social disability & 0.0 & 0.0 \\
Handicap & 0.0 & \\
Total OHIP & 4.0 & & 0.0 \\
\hline
\end{tabular}

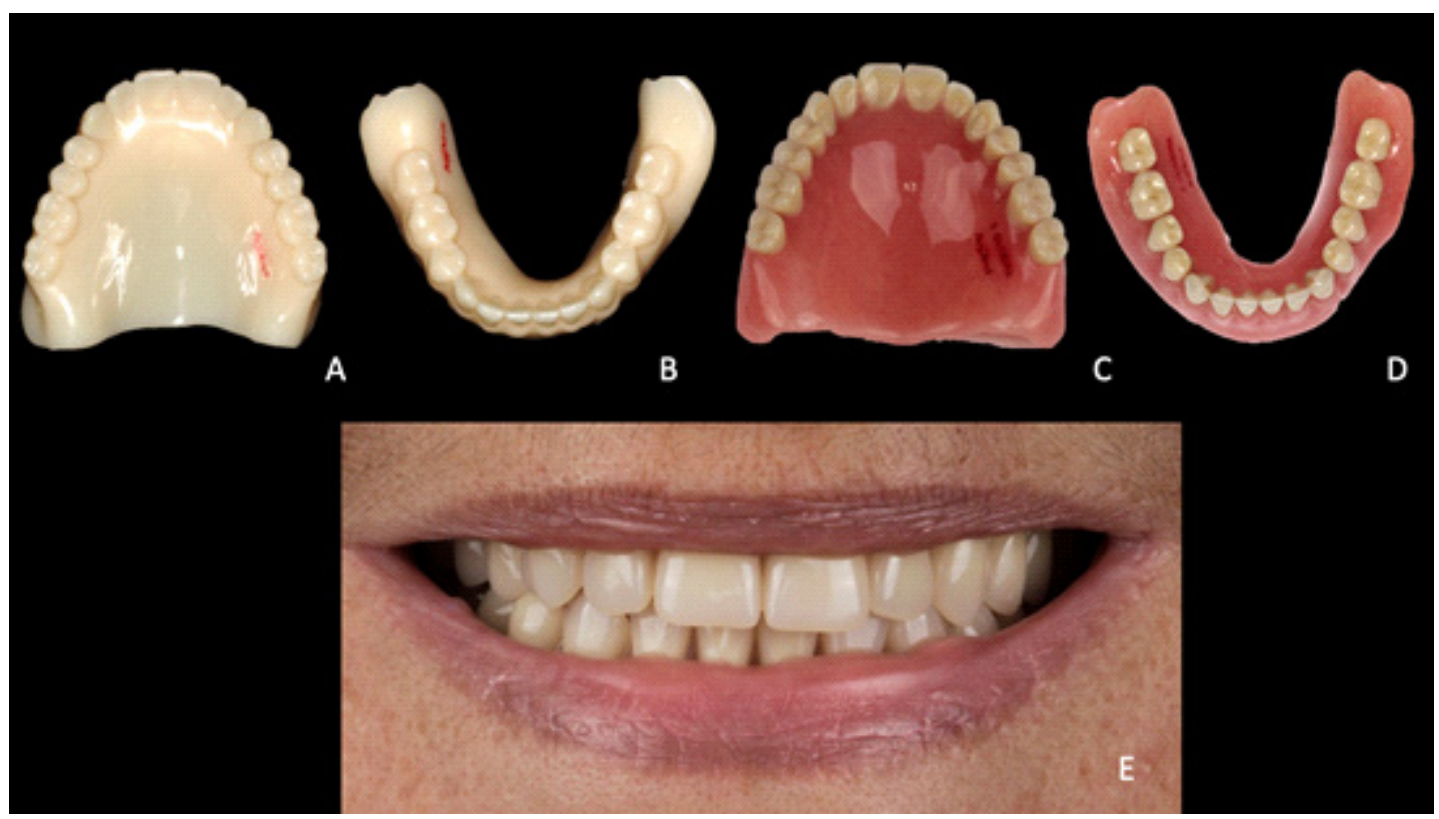

Figure 3. A and B. Maxillary and mandibular testing denture. C and D. Maxillary and mandibular digital denture. E. Patient's smile with new digital dentures. 
Considering that both dentures had no additional retention besides ridge and muscles, similar X50 values (reference unit for analysis of masticatory performance by sieving method) were found (6.9 for conventional denture and 7.0 for digital denture). On the contrary, literature shows that implant-supported dentures present better masticatory performance [22-24]. Assuming that the patient reported better retention for digital dentures, the reduction of laboratorial steps in digital technique may has influenced this result since resin polymerization shrinkage observed in the last laboratorial step for conventional denture influences denture dimension and retention [6-8].

As a consequence, a reduced number of follow-up sessions was needed for digital dentures. The dimensional stability promoted by CAD/CAM technology probably reduced base and occlusal adjustments [6-8]. The patient also reported better comfort and satisfaction with digital dentures, which is probably related to better stability and less adjustment sessions.

A total of three clinical sessions were required for fabrication of digital dentures with CAD/CAM technology. Literature reports digital dentures inserted with only two clinical sessions but testing dentures were not evaluated in those studies $[1,6-8]$. It is important to advise that professional skills about CAD/CAM system are mandatory for fabrication of digital dentures with less clinical sessions [5]. So, the professionals must be properly trained about CAD/CAM system before using such technology in patients.

Contrary to digital dentures, five clinical sessions were needed for fabrication of conventional dentures. So, CAD/CAM technology represents a faster treatment alternative for those elderly patients with limitations for displacement to dental office.

This study also evaluated the influence of CAD/CAM technology on masticatory performance. Previous clinical studies comparing digital and conventional dentures did not conduct such analysis, which is relevant for quality of life in edentulous patients [13]. However, this evaluation was performed with a single patient, suggesting further studies with higher sample size for confirmation of those results.

\section{CONCLUSION}

In conclusion, digital denture was a viable treatment alternative for edentulous patients. According to the clinical case, the variables satisfaction, comfort and retention were more satisfactory in the digital prosthesis for the studied patient. For this case, digital denture required less follow-up sessions compared to conventional denture. Similar quality of life and masticatory performance was found for both dentures. However, controlled and randomized clinical trials are required to reveal the real benefits of this treatment alternative compared to the conventional denture.

\section{Collaborators}

AFP CARREIRO, ACSP TÔRRES, and AF LIRA participated in the design, definition of intellectual content, literature search, clinical studies and experimental studies. RG CARDOSO, LA MELO, and $\mathrm{V}$ COOPER participated in the design, definition of intellectual content, literature search, clinical studies, data acquisition, data analysis, statistical analysis, manuscript preparation, manuscript editing, and manuscript review.

\section{REFERENCES}

1. Fang JH, An X, Jeong SM, Choi BH. Digital immediate denture: A clinical report. J Prosthet Dent. 2018;119:698-701. https:// dx.doi.org/10.1016/j.prosdent.2017.06.004

2. Goodacre CJ, Garbacea A, Naylor WP, Daher T. CAD/ CAM fabricated complete dentures: concepts and clinical methods of obtaining required morphological data. J Prosthet Dent. 2012;107:34-46. https://dx.doi. org/10.1016/S0022-3913(12)60015-8

3. Infante L, Yilmaz B, McGlumphy E, Finger I. Fabricating complete dentures with CAD/CAM technology. J Prosthet Dent. 2014;111(1):351-355. https://dx.doi.org/10.1016/j. prosdent.2013.10.014

4. Fang JH, An X, Jeong SM, Choi BH. Digital intraoral scanning technique for edentulous jaws. J Prosthet Dent. 2018;119:733-735. https://dx.doi.org/10.1016/j.prosdent.2017.05.008

5. Patzelt SB, Vonau S, Stampf S, Att W. Assessing the feasibility and accuracy of digitizing edentulous jaws. J Am Dent Assoc. 2013;144:914-920. https://dx.doi.org/10.14219/jada. archive.2013.0209

6. Kattadiyil MT, Goodacre CJ, Baba NZ. CAD/CAM complete dentures: a review of two commercial fabrication systems. J Calif Dent Assoc. 2013;41:407-416.

7. Bidra AS, Taylor TD, Agar JR. Computer-aided technology for fabricating complete dentures: systematic review of historical background, current status, and future perspectives. J Prosthet Dent. 2013;109:361-366. https://dx.doi.org/10.1016/S00223913(13)60318-2

8. Infante L, Yilmaz B, McGlumphy E, Finger I. Fabricating complete dentures with CAD/CAM technology. J Prosthet 
Dent. 2014; 111:351-355. https://dx.doi.org/10.1016/j. prosdent.2013.10.014

9. Al-Fouzan AF, Al-Mejrad LA, Albarrag AM. Adherence of Candida to complete denture surfaces in vitro: A comparison of conventional and CAD/CAM complete dentures. J Adv Prosthodont. 2017;9:402-408. https://dx.doi.org/10.4047/ jap.2017.9.5.402

10. Steinmassl O, Offermanns V, Stöckl W, Dumfahrt H, Grunert I, SteinmassI PA. In Vitro Analysis of the fracture resistance of CAD/CAM denture base resins. Materials (Basel). 2018;11:E401. https://dx.doi.org/10.3390/ma11030401

11. Wimmer T, Eichberger M, Lümkemann N, Stawarczyk B. Accuracy of digitally fabricated trial dentures. J Prosthet Dent. 2018;9:942-947. https://dx.doi.org/10.1016/j. prosdent.2017.06.020

12. Hwang HJ, Lee SJ, Park EJ, Yoon HI. Assessment of the trueness and tissue surface adaptation of CAD-CAM maxillary denture bases manufactured using digital light processing. J Prosthet Dent 2018;S0022-3913:30227-0. https://dx.doi. org/10.1016/j.prosdent.2018.02.018

13. Kattadiyil MT, Jekki R, Goodacre CJ, Baba NZ. Comparison of treatment outcomes in digital and conventional complete removable dental prosthesis fabrications in a predoctoral setting. J Prosthet Dent. 2015;114:818-825. https://dx.doi. org/10.1016/j.prosdent.2015.08.001

14. Allen F, Locker DA. A modified short version of the oral health impact profile for assessing health-related quality of life in edentoulous adults. Int J Prosthodont. 2002;15:446-450.

15. Slagter AP, Olthoff LW, Bosman F, Steen WH. Masticatory ability, denture quality, and oral conditions in edentulous subjects. J Prosthet Dent. 1992;68:299-307.

16. Sato Y, Hamada S, Akagawa Y, Tsuga K. A method for quantifying overall satisfaction of complete dentures patients. J Oral Rehab. 2000;27:952-957. https://dx.doi.org/10.1046/ j.1365-2842.2000.00579.x
17. Cunha EFS. Avaliação de prótese total bimaxilar em função das características da área basal [tese]. São Paulo: Universidade de São Paulo; 2004.

18. Cardoso RG, Melo LA, Barbosa GAS, Calderon PS, Germano $A R$, Junior WM, et al. Impact of mandibular conventional denture and overdenture on quality of life and masticatory efficiency. Braz Oral Res. 2016;30:e102. https://dx.doi. org/10.1590/1807-3107BOR-2016.vol30.0102

19. Heydecke G, Locker D, Awad MA, Lund JP, Feine JS. Oral and general health-related quality of life with conventional and implant dentures. Community Dent Oral Epidemiol. 2003;31:161-168. https://dx.doi.org/10.1034/j.1600-0528.2003.00029.x

20. Borges TF, Mendes FA, Oliveira TR, Gomes VL, Prado CJ, Neves FD. Mandibular overdentures with immediate loading: satisfaction and quality of life. Int J Prosthodont 2011;24:534-539.

21. Preciado A, Del Río J, Suárez-García MJ, Montero J, Lynch $C D$, Castillo-Oyagüe R. Differences in impact of patient and prosthetic characteristics on oral health-related quality of life among implant-retained overdenture wearers. J Dent. 2012;40:857-865. https://dx.doi.org/10.1016/j. jdent.2012.07.006

22. Ribeiro JA, Resende CM, Lopes AL, Mestriner WJ, Roncalli $A G$, Farias-Neto $A$, et al. Evaluation of complete denture quality and masticatory efficiency in denture wearers. Int J Prosthodont. 2012;25:625-630.

23. Fueki K, Kimoto K, Ogawa T, Garrett NR. Effect of implantsupported or retained dentures on masticatory performance: a systematic review. J Prosthet Dent. 2007; 98:470-477. https://dx.doi.org/10.1016/S0022-3913(07)60147-4

24. Farias Neto A, Pereira BM, Xitara RL. The influence of mandibular implant-retained overdentures in masticatory efficiency. Gerodontology. 2012; 29:650-655. https://dx.doi. org/10.1111/j.1741-2358.2011.00539.x

Received on: 30/3/2020

Final version resubmitted on: 17/4/2020

Approved on: 2/6/2020 